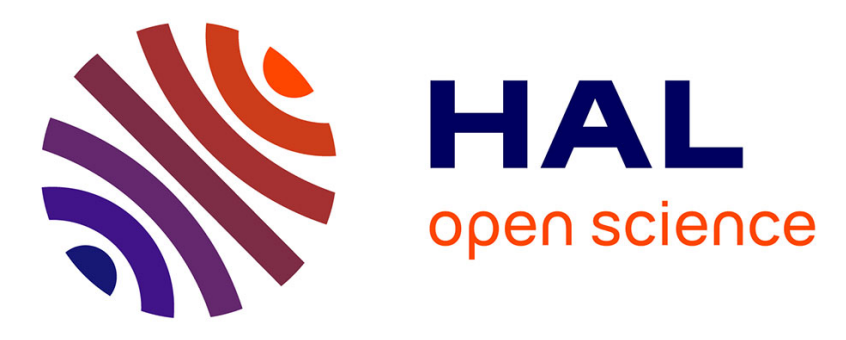

\title{
Two-Step One-Pot Synthesis of Benzoannulated Spiroacetals by Suzuki-Miyaura Coupling/Acid-Catalyzed Spiroacetalization
}

Alexey N. Butkevich, Andrei Corbu, Lieven Meerpoel, Ian Stansfield, Patrick Angibaud, Pascal Bonnet, Janine Cossy

\section{To cite this version:}

Alexey N. Butkevich, Andrei Corbu, Lieven Meerpoel, Ian Stansfield, Patrick Angibaud, et al.. TwoStep One-Pot Synthesis of Benzoannulated Spiroacetals by Suzuki-Miyaura Coupling/Acid-Catalyzed Spiroacetalization. Organic Letters, 2012, 14, pp.4998 - 5001. 10.1021/ol302088w . hal-03102296

\section{HAL Id: hal-03102296 \\ https://hal.science/hal-03102296}

Submitted on 7 Jan 2021

HAL is a multi-disciplinary open access archive for the deposit and dissemination of scientific research documents, whether they are published or not. The documents may come from teaching and research institutions in France or abroad, or from public or private research centers.
L'archive ouverte pluridisciplinaire HAL, est destinée au dépôt et à la diffusion de documents scientifiques de niveau recherche, publiés ou non, émanant des établissements d'enseignement et de recherche français ou étrangers, des laboratoires publics ou privés. 


\title{
Two-Step One-Pot Synthesis of Benzoannulated Spiroacetals by Suzuki-Miyaura Coupling/Acid-Catalyzed Spiroacetalization
}

XXXX

Vol. XX, No. XX 000-000

\author{
Alexey N. Butkevich, ${ }^{\dagger}$ Andrei Corbu, ${ }^{\dagger}$ Lieven Meerpoel, ${ }^{\ddagger}$ Ian Stansfield, ${ }^{\S}$ \\ Patrick Angibaud, ${ }^{\S}$ Pascal Bonnet, ${ }^{\ddagger}$ and Janine Cossy ${ }^{*, \dagger}$
}

Laboratoire de Chimie Organique, ESPCI ParisTech, CNRS, 10 rue Vauquelin, 75231

Paris Cedex 05, France, Janssen Research \& Development, Division of Janssen-Cilag

S.A., Oncology and Medicinal Chemistry, Campus de Maigremont, 27106 Val de Reuil,

Cedex, France, and Janssen Research \& Development, Division of Janssen

Pharmaceutica N.V., Turnhoutsweg 30, 2340 Beerse, Belgium

janine.cossy@espci.fr

Received July 27, 2012

ABSTRACT

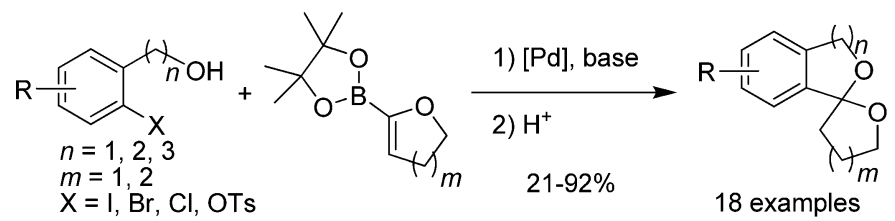

Substituted benzoannulated spiroacetals were prepared from (2-haloaryl)alkyl alcohols and dihydropyranyl or dihydrofuranyl pinacol boronates using a Suzuki-Miyaura coupling followed by an acid-catalyzed spirocyclization. Application of the reaction to a glycal boronate provides an approach to annulated spiroacetals in enantiopure form.

The spiroacetal ring system, in particular 1,6-dioxaspiro[4.4]nonanes, 1,6-dioxaspiro[4.5]decanes, and 1,7-dioxaspiro[5.5] undecanes, is present in a variety of natural products of different origins. ${ }^{1}$ Several benzoannulated spiroacetals, such as rubromycins, heliquinomycin, papulacandin, paecilospirone, and berkelic acid, have demonstrated potent biological activity ${ }^{2}$ and therefore remain attractive synthetic targets.

\footnotetext{
$\dagger$ ESPCI ParisTech.

$\$$ Janssen Research \& Development, Janssen Pharmaceutica N.V.

$\S$ Janssen Research \& Development, Oncology and Medicinal Chemistry, Campus de Maigremont.

(1) Aho, J. E.; Pihko, P. M.; Rissa, T. K. Chem. Rev. 2005, 105, 44064440. Denmark, S. E.; Regens, C. S.; Kobayashi, T. J. Am. Chem. Soc. 2007, 129, 2774-2776. Liu, G.; Wurst, J. M.; Tan, D. S. Org. Lett. 2009, $11,3670-3673$

(2) Sperry, J.; Wilson, Z. E.; Rathwell, D. C. K.; Brimble, M. A. Nat. Prod. Rep. 2010, 27, 1117-1137 and references cited therein.

(3) Tsang, K. Y.; Brimble, M. A.; Bremner, J. B. Org. Lett. 2003, 5, 4425-4427. Sörgel, S.; Azap, C.; Reissig, H.-U. Org. Lett. 2006, 8, 48754878. Mainkar, P. S.; Johny, K.; Prabhakar Rao, T.; Chandrasekhar, S. J. Org. Chem. 2012, 77, 2519-2525.

(4) Waters, S. P.; Fennie, M. W.; Kozlowski, M. C. Tetrahedron Lett. 2006, 47, 5409-5413.
}

Spiroacetals have been prepared by acid-catalyzed cyclization of $\omega, \omega^{\prime}$-dihydroxyketones, ${ }^{3}$ 1,3-dipolar cycloaddition, ${ }^{4}$ oxidative enolate coupling, ${ }^{5}$ addition of 2-lithiofurans to phenylacetaldehydes followed by cyclization, ${ }^{6}$ or an aromatic Pummerer-type reaction. ${ }^{7}$ Metal-catalyzed (Ir, Rh, and $\mathrm{Au}$ ) double hydroalkoxylation of disubstituted alkynes provides benzoannulated spiroacetals; however these reactions are rarely regioselective. ${ }^{8}$ Several syntheses of

(5) Lindsey, C. C.; Wu, K. L.; Pettus, T. R. R. Org. Lett. 2006, 8, 2365-2367.

(6) Qin, D.; Ren, R. X.; Siu, T.; Zheng, C.; Danishefsky, S. J. Angew. Chem., Int. Ed. 2001, 40, 4709-4713.

(7) Akai, S.; Kakiguchi, K.; Nakamura, Y.; Kuriwaki, I.; Dohi, T.; Harada, S.; Kubo, O.; Morita, N.; Kita, Y. Angew. Chem., Int. Ed. 2007, 46, 7458-7461.

(8) Fugami, K.; Hagiwara, N.; Okeda, T.; Kosugi, M. Chem. Lett. 1998, 81-82. Li, X.; Chianese, A. R.; Vogel, T.; Crabtree, R. H. Org. Lett. 2005, 7, 5437-5440. Messerle, B. A.; Vuong, K. Q. Organometallics 2007, 26, 3031-3040. Zhang, Y.; Xue, J.; Xin, Z.; Xie, Z.; Li, Y. Synlett 2008, 2008, 940-944. Selvaratnam, S.; Ho, J. H. H.; Huleatt, P. B.; Messerle, B. A.; Chai, C. L. L. Tetrahedron Lett. 2009, 50, 1125-1127. Ho, J. H. H.; Hodgson, R.; Wagler, J.; Messerle, B. A. Dalton Trans. 2010, 39, 4062-4069. Ho, J. H. H.; Choy, S. W. S.; Macgregor, S. A.; Messerle, B. A. Organometallics 2011, 30, 5978-5984. 
benzoannulated spiroacetals have relied on a Pd-catalyzed cross-coupling between aryl halides and stannylated dihydropyrans or dihydropyranyl silanols leading to 6-aryl-3,4dihydro- $2 H$-pyrans. These pyrans underwent spirocyclization with a side chain at the $\mathrm{C}-2$ position of the aryl group when reacted with an electrophilic epoxidation reagent, such as DMDO or $m$-CPBA. ${ }^{9}$ Recently, the treatment of 6-( $\omega$-hydroxyalkyl)-3,4-dihydro- $2 H$-pyrans and related dihydrofurans and tetrahydrooxepins with binaphtholphosphoric acids $^{10 \mathrm{a}}$ or binaphthol-derived iminodiphosphoric acids ${ }^{10 b}$ has been reported to lead to optically active spiroacetals.

Due to the known toxicity and persistence of organostannanes, and as the preparation of silanols has to be realized in several steps, we have planned to access benzoannulated spiroacetals $\mathbf{A}$ in an efficient convergent manner from the corresponding (2-haloaryl)alkyl alcohols $\mathbf{B}$ and pinacol boronates $\mathbf{C}$, employing a one-pot Suzuki-Miyaura coupling/acid-catalyzed spiroacetalization approach (Scheme 1).

Scheme 1. Retrosynthetic Approach

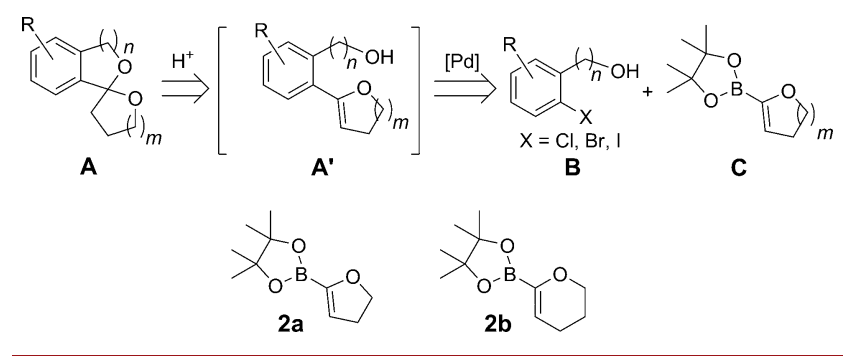

In a test reaction, the starting boronate $2 \mathbf{b}^{11}$ was reacted with 2-bromobenzyl alcohol 1a followed by an acidic treatment of the obtained intermediate 3a. At first, different palladium catalysts and bases were tested in order to optimize the conditions of the Suzuki-Miyaura coupling. The reaction was carried out in 1,4-dioxane $/ \mathrm{H}_{2} \mathrm{O}(3: 1)$ at $100{ }^{\circ} \mathrm{C}$ under microwave irradiation. Among the palladium catalysts and bases tested, $\mathrm{Pd}(\mathrm{dppf}) \mathrm{Cl}_{2}(5 \mathrm{~mol} \%)$ in the presence of $\mathrm{Na}_{2} \mathrm{CO}_{3}$ or $\mathrm{NaOH}$ ( 2 equiv) led to the highest yield of the coupling product $3 \mathbf{a}(82 \%)$. The desired spiroacetal 4a was also obtained in $6 \%$ yield, likely due to Lewis acid properties of the Pd catalyst (Table 1, entry 3 ). To achieve the complete transformation of $\mathbf{3 a}$ into $\mathbf{4 a}$, $p$-TsOH ( 3 equiv) was added to the reaction mixture, leading directly to spiroacetal $\mathbf{4 a}$ in $86 \%$ yield (Table 1 ,

(9) Denmark, S.; Neuville, L. Org. Lett. 2000, 2, 3221-3224. Wurst, J. M.; Liu, G.; Tan, D. S. J. Am. Chem. Soc. 2011, 133, 7916-7925. Potuzak, J. S.; Moilanen, S. B.; Tan, D. S. J. Am. Chem. Soc. 2005, 127, 13796-13797. Dubois, E.; Beau, J.-M. J. Chem. Soc., Chem. Commun. 1990, 1191-1192. Elsley, D. A.; MacLeod, D.; Miller, J. A.; Quayle, P.; Davies, G. M. Tetrahedron Lett. 1992, 33, 409-412.

(10) (a) Sun, Z.; Winschel, G. A.; Borovika, A.; Nagorny, P. J. Am. Chem. Soc. 2012, 134, 8074-8077. (b) Corić, I.; List, B. Nature 2012, 483, 315-319.

(11) Boronate $\mathbf{2 b}$ was prepared on a multigram scale by metalation of 3,4 -dihydro- $2 H$-pyran with the $n$-BuLi/ $t$-BuOK system followed by treatment with trimethyl borate, pinacol, and acetic acid (see Supporting Information). entry 4). The palladium catalyst loading could be successfully decreased to $2 \mathrm{~mol} \%$; however using smaller amounts of catalyst $(0.5 \mathrm{~mol} \%)$ resulted in a significantly lower yield of $\mathbf{4 a}$ (Table 1, entry 5).

Table 1. Optimization of the Reaction Conditions
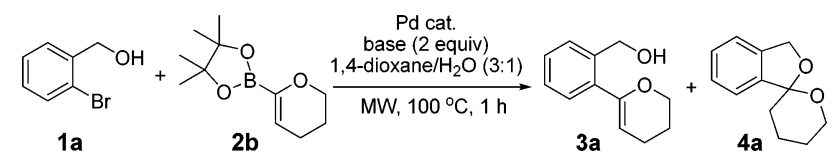

\begin{tabular}{|c|c|c|c|c|}
\hline entry & $\begin{array}{l}\text { Pd cat. } \\
(\mathrm{mol} \%)\end{array}$ & base & $\begin{array}{c}\text { yield } \\
\mathbf{3 a}\end{array}$ & $\begin{array}{c}\text { yield } \\
\mathbf{4 a}\end{array}$ \\
\hline 1 & $\mathrm{Pd}\left(\mathrm{PPh}_{3}\right)_{4}(5)$ & $\mathrm{Na}_{2} \mathrm{CO}_{3}$ & $67 \%$ & - \\
\hline 2 & $\mathrm{Pd}(\mathrm{MeCN})_{2} \mathrm{Cl}_{2}(5) \mathrm{PCy}_{3}(10)$ & $\mathrm{Na}_{2} \mathrm{CO}_{3}$ & $64 \%$ & $3 \%$ \\
\hline 3 & $\mathrm{Pd}(\mathrm{dppf}) \mathrm{Cl}_{2}(5)$ & $\mathrm{Na}_{2} \mathrm{CO}_{3}$ & $82 \%$ & $6 \%$ \\
\hline $4^{a}$ & $\mathrm{Pd}(\mathrm{dppf}) \mathrm{Cl}_{2}(2)$ & $\mathrm{NaOH}$ & - & $86 \%^{b}$ \\
\hline $5^{a}$ & $\mathrm{Pd}(\mathrm{dppf}) \mathrm{Cl}_{2}(0.5)$ & $\mathrm{NaOH}$ & - & $58 \%^{b}$ \\
\hline
\end{tabular}

${ }^{a}$ Reaction time 10 min. ${ }^{b}$ Yield of $\mathbf{4 a}$ after cyclization with $\mathrm{TsOH}$ ( 3 equiv) for $10 \mathrm{~min}$ at $\mathrm{rt}$.

Spiroacetals of type A were prepared from various (2-haloaryl)alkyl alcohols $\mathbf{B}$, such as iodide $\mathbf{1 b}$, chloride 1c, and tosylate 1d, by using the conditions reported in Table 2 .

Table 2. Scope of the Leaving Group ${ }^{a}$

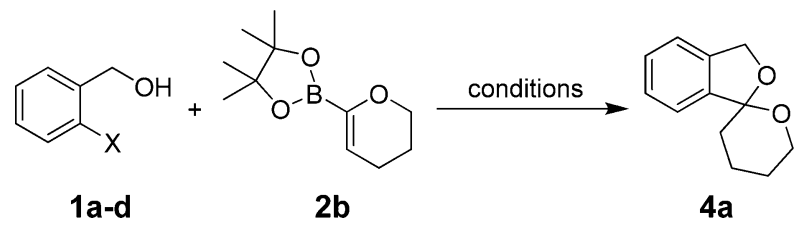

\begin{tabular}{cllr}
\hline entry & X, 1 & cond & yield 4a \\
\hline 1 & Br, 1a & A & $86 \%$ \\
2 & I, 1b & A & $92 \%$ \\
3 & Cl, 1c & A & $0 \%$ \\
4 & Cl, 1c & B & $84 \%$ \\
5 & OTs, 1d & A or B & $0 \%$ \\
6 & OTs, 1d & C & $21 \%$
\end{tabular}

${ }^{a}$ Conditions A: $\mathrm{Pd}(\mathrm{dppf}) \mathrm{Cl}_{2}$ (2 $\left.\mathrm{mol} \%\right), \mathrm{NaOH}$ (2 equiv), 1,4-dioxane/ $\mathrm{H}_{2} \mathrm{O}(3: 1), \mathrm{MW}, 100^{\circ} \mathrm{C}, 10 \mathrm{~min}$, then $\mathrm{TsOH} \cdot \mathrm{H}_{2} \mathrm{O}$ (2.2 equiv), rt, $10 \mathrm{~min}$. Conditions B: $\mathrm{Pd}\left(\mathrm{MeCN}_{2} \mathrm{Cl}_{2}(3 \mathrm{~mol} \%)\right.$, XPhos $(6 \mathrm{~mol} \%), \mathrm{NaOH}$ (2 equiv), 1,4-dioxane $/ \mathrm{H}_{2} \mathrm{O}(3: 1), \mathrm{MW}, 100{ }^{\circ} \mathrm{C}, 10 \mathrm{~min}$, then $\mathrm{TsOH} \cdot \mathrm{H}_{2} \mathrm{O}$ (2.2 equiv), rt, $10 \mathrm{~min}$. Conditions C: $\mathrm{Pd}(\mathrm{OAc})_{2}(2 \mathrm{~mol} \%)$, BrettPhos $\left(4 \mathrm{~mol} \%\right.$ ), $\mathrm{K}_{3} \mathrm{PO}_{4}$ (3 equiv), $t$ - BuOH, MW, $110^{\circ} \mathrm{C}, 2 \mathrm{~h}$, then TsOH $\cdot \mathrm{H}_{2} \mathrm{O}$ (5.5 equiv), $\mathrm{rt}$ (monitored by TLC).

2-Iodobenzyl alcohol $\mathbf{1 b}$ was converted to $\mathbf{4 a}$ in $92 \%$ yield under conditions A (Table 2, entry 2), while 2-chlorobenzyl alcohol 1c was not reactive and required a more active catalytic system, $\mathrm{Pd}(\mathrm{MeCN})_{2} \mathrm{Cl}_{2}(3 \mathrm{~mol} \%) / \mathrm{XPhos}$ $(6 \mathrm{~mol} \%)$, to produce $4 \mathrm{a}$ in $84 \%$ yield after acid-catalyzed cyclization (conditions B, Table 2 , entry 4 ). The crosscoupling with 2-(hydroxymethyl)phenyl tosylate 1d was 
Table 3. Substitution of the Aromatic Ring: Scope and Limitations ${ }^{a}$

\begin{tabular}{|c|c|c|c|c|c|c|c|}
\hline entry & ArX, 1e-n & cond & $\begin{array}{l}\text { product } \\
\text { (yield) }\end{array}$ & entry & ArX, 1e-n & cond & $\begin{array}{c}\text { product } \\
\text { (yield) }\end{array}$ \\
\hline 1 & $1 e$ & A & $4 e(74 \%)$ & 6 & $1 \mathbf{j}$ & $A$ & $4 j(34 \%)$ \\
\hline 2 & $1 f$ & A & $4 f(72 \%)$ & 7 & $1 k$ & $A$ & $4 \mathbf{k}(60 \%)$ \\
\hline 3 & $1 \mathrm{~g}$ & A & $\mathbf{4 g}(90 \%)$ & 8 & 11 & B & $4 \mathrm{l}(38 \%)$ \\
\hline 4 & $1 \mathrm{~h}$ & A & 4h $(78 \%)$ & 9 & $1 \mathrm{~m}$ & C & $\begin{array}{c}\mathrm{MeO} \\
\mathbf{4 m}(67 \%)\end{array}$ \\
\hline 5 & $1 \mathrm{i}$ & A & $4 i(84 \%)$ & 10 & $1 \mathrm{n}$ & C & $4 n(45 \%)$ \\
\hline
\end{tabular}

${ }^{a}$ Conditions A: $\mathrm{Pd}(\mathrm{dppf}) \mathrm{Cl}_{2}(2 \mathrm{~mol} \%), \mathrm{NaOH}$ (2 equiv), 1,4-dioxane $/ \mathrm{H}_{2} \mathrm{O}(3: 1), \mathrm{MW}, 100{ }^{\circ} \mathrm{C}, 10 \mathrm{~min}$, then TsOH$\cdot \mathrm{H}_{2} \mathrm{O}(2.2 \mathrm{equiv})$, rt, $10 \mathrm{~min}$. Conditions B: $\mathrm{Pd}\left(\mathrm{PPh}_{3}\right)_{2} \mathrm{Cl}_{2}(5 \mathrm{~mol} \%), \mathrm{Na}_{2} \mathrm{CO}_{3}$ (2 equiv), 2,2,2-trifluoroethanol, $\mathrm{MW}, 100{ }^{\circ} \mathrm{C}, 1 \mathrm{~h}$. Conditions $\mathrm{C}: \mathrm{Pd}(\mathrm{MeCN})_{2} \mathrm{Cl} 2(3 \mathrm{~mol} \%), \mathrm{XPhos}$ (6 $\mathrm{mol} \%$ ), $\mathrm{NaOH}$ (2 equiv), 1,4-dioxane $/ \mathrm{H}_{2} \mathrm{O}(3: 1), \mathrm{MW}, 100{ }^{\circ} \mathrm{C}, 10 \mathrm{~min}$, then $\mathrm{TsOH} \cdot \mathrm{H}_{2} \mathrm{O}$ (2.2 equiv), rt, $10 \mathrm{~min}$.

Table 4. Side Chain and Cycle Size Variation ${ }^{a}$

entry $\quad$ boronate $\begin{gathered}\text { product } \\ \text { (yield) } \\ (\mathrm{dr})\end{gathered}$

${ }^{a}$ Conditions: $\mathrm{Pd}(\mathrm{dppf}) \mathrm{Cl}_{2}\left(2 \mathrm{~mol} \%\right.$ ), $\mathrm{NaOH}$ (2 equiv), 1,4-dioxane $/ \mathrm{H}_{2} \mathrm{O}(3: 1), \mathrm{MW}, 100{ }^{\circ} \mathrm{C}, 10 \mathrm{~min}$, then $\mathrm{TsOH} \cdot \mathrm{H}_{2} \mathrm{O}(2.2$ equiv), rt, $10 \mathrm{~min}$. 
difficult to achieve and required an even more active catalyst $\left(\operatorname{Pd}(0) /\right.$ BrettPhos$^{12}$ (conditions C, Table 2, entry 6). Importantly, under conditions $\mathrm{A}$, chloride and tosylate substituents present on the aromatic ring are tolerated and not involved in cross-coupling reactions. The results are summarized in Table 3.

Substituted 2-halobenzyl alcohols $\mathbf{1 e}-\mathbf{1 n}$ were transformed into the corresponding spiroacetals $\mathbf{4 e}-\mathbf{4 n}$ in moderate to excellent yields $(38-90 \%)$. As can be concluded from the results, electron-withdrawing groups were generally well tolerated (Table 3 , entries 1 and 4), while very electron-rich substrates suffered from diminished yields due to side reactions during the cyclization step. Alternative reaction conditions (conditions $\mathrm{B}$ ) had to be employed to attain practical yields (Table 3, entry 8).

Benzoannulated [5,5]-, [5,6]-, [5,7]- and [6,6]-spiroacetals were successfully prepared under conditions A depending on the length of the hydroxyalkyl side chain of the aryl halide as well as on the ring size of the boronates $\mathbf{2 a , b}$ (Table 4, entries 1-4). A diastereomeric ratio of 60:40 was observed when secondary benzyl alcohols 1 s and 1t were used; however, the diastereomeric spiroacetals were found to interconvert rapidly in the presence of a catalytic amount of acid (Table 4, entries 5 and 6).

To demonstrate the applicability of our method to the synthesis of chiral spiroacetals, boronate ester 6, prepared from trimethyl-D-glucal $\mathbf{5},{ }^{13}$ was reacted with either $\mathbf{1 a}$ or $1 \mathrm{c}$ in the presence of a $\mathrm{Pd}$ catalyst and $\mathrm{Na}_{2} \mathrm{CO}_{3}$ as a base in anhydrous 1,4-dioxane or $\mathrm{MeCN}$ (use of $\mathrm{NaOH}$ in a 1,4-dioxane/water mixture resulted in complete

(12) (a) Bhayana, B.; Fors, B. P.; Buchwald, S. L. Org. Lett. 2009, 11 , 3954-3957. (b) Pd/XPhos-catalyzed Suzuki-Miyaura coupling of aryl tosylates has also been reported but was not successful in our case; see: Nguyen, H. N.; Huang, X.; Buchwald, S. L. J. Am. Chem. Soc. 2003, 125, 11818-11819.

(13) (a) Kikuchi, T.; Takagi, J.; Ishiyama, T.; Miyaura, N. Chem. Lett. 2008, 37, 664-665. (b) Kikuchi, T.; Takagi, J.; Isou, H.; Ishiyama, T.; Miyaura, N. Chem.-Asian J. 2008, 3, 2082-2090. protodeboronation of 6 to the starting glycal 5). The product of this reaction was spiroacetal 7 as the anomerically stabilized diastereoisomer, isolated in $55-63 \%$ yield (Scheme 2).

Scheme 2. Preparation of 2-Deoxy-D-glucose-Derived Spiroacetal $7^{a}$

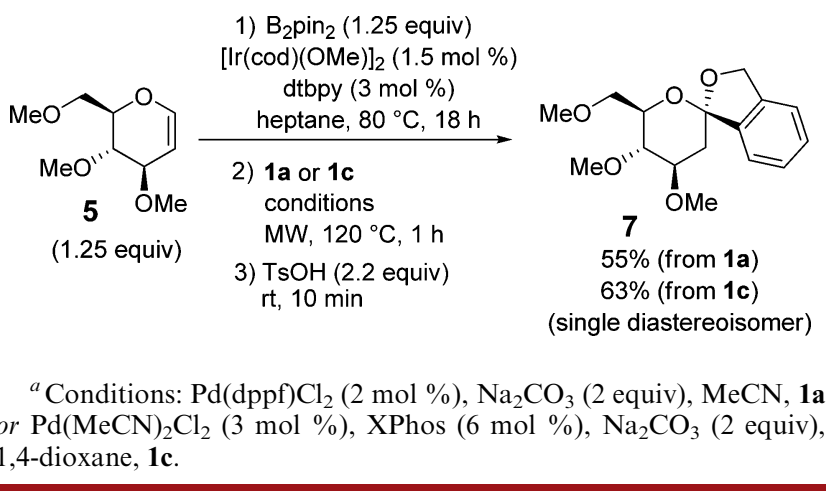

In summary, we have developed a rapid convergent microwave-assisted synthesis of benzoannulated spiroacetals using a one-pot Suzuki-Miyaura coupling reaction/ spiroacetalization. This versatile and chemoselective process is potentially applicable to the synthesis of complex biologically active natural products.

Acknowledgment. Janssen Pharmaceutica is gratefully acknowledged for financial support.

Supporting Information Available. Full experimental details and characterization data $\left({ }^{1} \mathrm{H}\right.$ NMR, ${ }^{13} \mathrm{C}$ NMR, IR, and HRMS) for all new compounds. This material is available free of charge via the Internet at http://pubs.acs.org.

The authors declare no competing financial interest. 